\title{
Revisiting residential self-selection issues: A life-oriented approach
}

\author{
Junyi Zhang \\ Hiroshima University, Japan \\ zjy@hiroshima-u.ac.jp
}

\begin{abstract}
It has been widely argued that residential self-selection stems from two sources: attitudes and socio-demographic traits. This argument would be true if decisions were made with respect to only residential choice and travel behavior. Because they are just a part of people's life choice, the influence of life choice on self-selection cannot be ignored. In this context, a life-oriented approach becomes relevant, where residential and travel decisions are interdependent not only with each other, but also with other life domains as a part of general life decisions. This paper conceptually argued and empirically confirmed the necessity of developing a life-oriented approach to reexamine residential self-selection issues. I proposed that life choices should be treated as an additional source of the self-selection, and dynamic interdependences between residential choice, travel behavior, and other life choices should be properly modeled. From a policy perspective, the life-oriented approach suggests that successful transport and land use policies should be designed together with policies in other significantly relevant sectors (e.g., health and environment) and such cross-sectoral policies could better contribute to the improvement of people's quality of life.
\end{abstract}

Keywords: residential self-selection, travel behavior, life-oriented approach, QOL

\section{$1 \quad$ Introduction}

It has been widely argued that residential self-selection refers to "the tendency of people to choose locations based on their travel abilities, needs and preferences" (Litman, 2005) and it results from two sources: attitudes and socio-demographic traits (Mokhtarian and Cao, 2008; Van Wee, 2009; Cao et al., 2009). Self-selection has a direct effect and an indirect effect on travel behavior via the residential choice (Van Wee, 2009). This argument may be true if decisions were made with respect to only residential and travel behavior. Because they are only a part of people's decisions on life choices, it may be worth reconsidering ways of analyzing the residential self-selection issue from the perspective of life choices. The decision on the residential choice and travel behavior should be called a "local decision" and that on the life choice a "global decision" (Figure 1). In other words, this discussion raises an issue of how to set decision-making boundaries. When a longer time is concerned, residential and travel behavior may have a two-way relationship. 


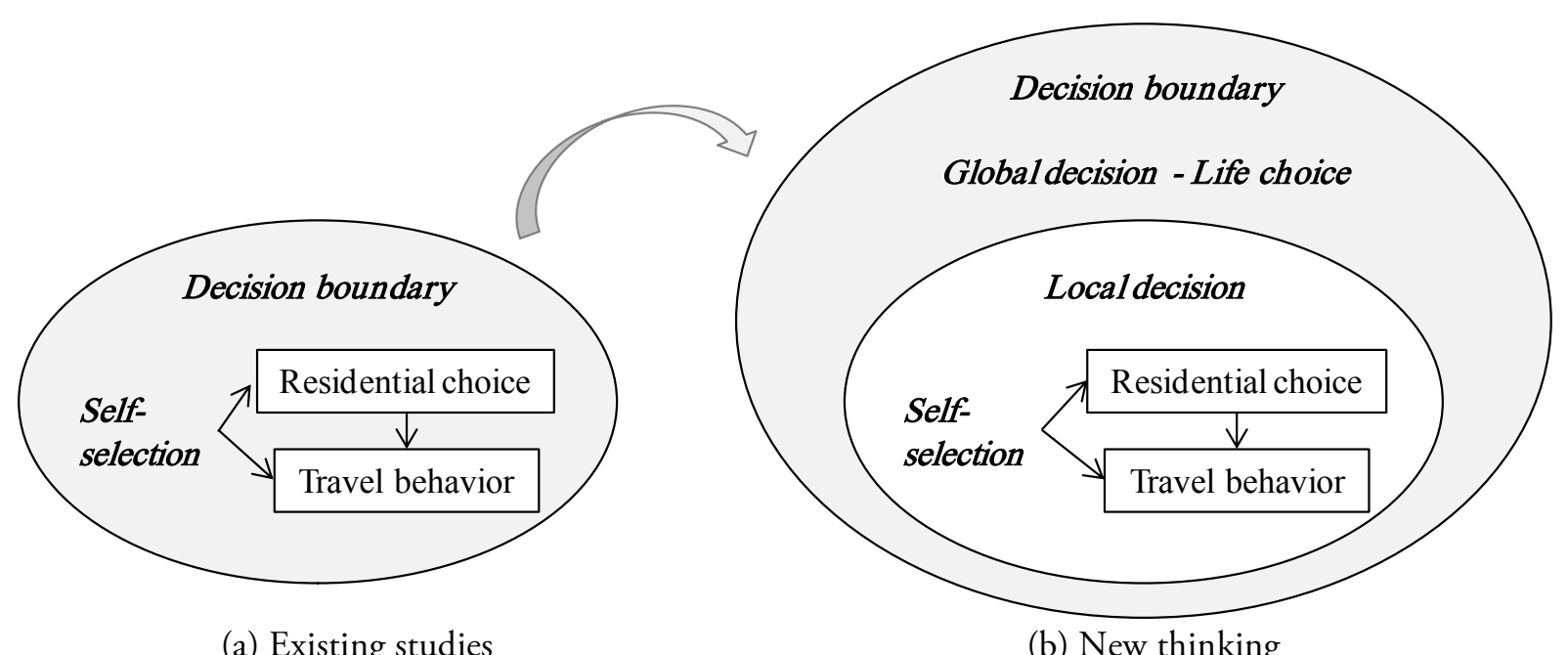

(a) Existing studies

(b) New thinking

Figure 1. Decision boundary

People's life choices are closely linked with their quality of life (QOL) (World Database of Happiness (http://www1.eur.nl/fsw/happiness/); Zhang and Xiong, 2013; Xiong and Zhang, 2014). QOL has been investigated regarding various life domains, such as residence (Heal and Chadsey-Rusch, 1985; Werner, 2011), neighborhood (Honold et al., 2012; Delmelle et al., 2013), health (De Hollander and Staatsen, 2003; Sturm and Cohen, 2004), education (Frisvold and Golberstein, 2011; Winters, 2011), work (Huang and Sverke, 2007; Tefft, 2012), family life (Greenhaus et al., 2003; Huang and Sverke, 2007), leisure and recreation (Leung and Lee, 2005; Lin et al., 2013), finance (Kaplan et al., 2008), and travel behavior (Abou-Zeid et al., 2012; Cao, 2013; Delmelle et al., 2013). Different life choices are usually decided over different time scales under the influence of limited time and monetary constraints as well as the various needs of households and their members. As a result, changes in one of life choices may influence other choices. Targeting the global decision of life choice, I have proposed a life-oriented approach (Zhang, 2010, 2012; Zhang et al., 2011, 2012b) to support cross-sectoral urban policy decisions. This approach argues that decisions on various life domains are interdependent. With respect to residential and travel behavior, the life-oriented approach argues that residential and travel decisions are interdependent not only with each other but also with other life domains. Therefore, the currently identified two sources may not be true causal factors of the self-selection, but rather may act as a surrogate for a set of life choice factors that do affect residential and travel behavior. From a practical perspective, the lifeoriented approach argues that different governmental sectors should collaborate with each other to improve people's QOL. Successful land use and transport policies should be decided together with policies in other significantly relevant sectors (e.g., health and environment). The above arguments suggest that the life-oriented approach is not only behaviorally oriented but also policy oriented.

To date, criticisms of unsuccessful cross-sectoral policies have been directed at the lack of better institutional governance (e.g., Stead, 2008; Cole et al., 2010). However, I argue that the lack of transdisciplinary approaches is more serious. The life-oriented approach is in line with such considerations and is expected to be useful in the analysis of self-selection.

The main purpose of this paper is to provide evidence of the necessity of revisiting residential selfselection issues from the perspective of life choice orientation, i.e., the life-oriented approach.

In the reminder of this paper, the life-oriented approach will be introduced in Section 2. Section 3 discusses the residential self-selection issue from the life choice perspective. In Section 4, evidence of behavioral interdependences based on two life choice surveys will be given. Challenges of the life-oriented approach in the analysis of residential self-selection will be discussed, and a new analysis framework will 
be proposed in Section 5. Finally, this study will be concluded by summarizing main arguments and future research issues in Section 6.

\section{$2 \quad$ Life-oriented approach}

I originally proposed the life-oriented approach for a transdisciplinary research project about the development of cross-sectoral urban planning and management methodologies ${ }^{2}$. The life-oriented approach argues that people's decisions on various life domains are not independent of each other and that an understanding of life choices should not be constrained by the boundary of any single discipline. It should be developed as a common decision support method for various public policies. In the case of transport policy, it reasons that travel results from various life decisions and therefore any understanding of travel behavior is secondary to a fundamental understanding of life choice decisions. From the behavior viewpoint, the ignorance and inability of understanding travel behavior from the life choice perspective may lead to a biased estimation of travel demand and behavioral changes, and from the transport policy viewpoint, the ignorance and inability may lead to a failure of consensus building. In the case of urban policy, the relevance and importance of the life-oriented approach is more obvious because the urban policy needs to reflect people's various life aspects into the policy decision-making process simultaneously.

\subsection{Current situations}

Surveys with more general behavior content are required to support the practice of the life-oriented approach. Taking Japan as an example, the first travel diary survey was implemented in the Hiroshima metropolitan area in 1967. Since then, similar surveys have been done in various cities. The national time use survey (called the Survey on Time Use and Leisure Activities, a legalized survey) has been conducted every five years since 1976. In the field of urban planning, a legalized Urban Planning Basic Survey in Japan has been done every five years in each city. However, these surveys totally ignored individuals' actual situations of life choices and behavior. In the next two subsections, I introduce two lifeoriented surveys.

\subsubsection{A cross-sectional survey for the life-oriented approach}

I pioneered a web-based life choice survey about nine major life domains and QOL evaluation in November 2010 (Zhang et al., 2011). Survey contents for different life domains are shown below.

1. Residence: location, duration, price, types, living area, distance to daily facilities, etc.

2. Family budgets: income and expenditure

3. Health: health condition, experience of accidents and illness, sleeping time, frequency and duration of physical exercises, and distance to places of physical exercise, etc.

4. Neighborhood: communication frequency, participation in community activities, etc.

5. Education and learning: academic degree, learning frequency and time, distance and major travel modes to different types of learning facilities, etc.

6. Job: location, commuting mode, job type, working days and hours per day, paid holidays in contract and number of holidays actually taken, working duration, etc.

7. Family life: in-home and out-of-home time use with family on weekdays and weekends, communication frequency with relatives, care giving, etc.

8. Leisure and recreation: discretionary time, activity time, frequency, distance to place, major travel mode, tourism (frequency, travel party, expenditure), Internet usage, etc.

\footnotetext{
${ }^{2}$ For details, refer to http://home.hiroshima-u.ac.jp/hitel/citi_qol_jp.html
} 
9. Travel behavior: driving license, ownership of different types of vehicles), major daily travel mode and the travel behavior with respect to each life domain (see above), etc.

In the above survey, travel behavior is not specified as a separate domain, but as a cross-domain behavior. The life-oriented approach argues that travel demand is derived from life decisions, as opposed to activity participation in activity-based approaches.

\subsubsection{A life history survey for the life-oriented approach}

The above survey captures life choices at a single time point. However, the relationship between residential and travel behavior may not be invariant over time, especially over the life course. Thus, I further conducted a web-based life history survey in November 2010 (Zhang et al., 2013) to investigate the following biographies. Here, biography is defined as a series of mobilities in each life domain over the life course, while mobility indicates a change occurring in each domain.

1. Residential biography: location of residence, income, house ownership, distance to varied facilities (railway, bus, school, hospital, park, supermarket, city hall);

2. Household structure biography: household size, members' attributes (age, gender, relation with householder);

3. Employment/Education biography: job category, commute time to job/school, accessibility to job/school, travel mode;

4. Car ownership biography: number of cars, user, fuel efficiency, use purpose and frequency.

The information for each biography includes mobility frequency, timing, and the details about household, individual, spatial, and housing factors. Similar surveys can be also found in transportation (e.g., Beige and Axhausen, 2008; Verhoeven, 2010; Oakil, 2013).

\subsection{Differences from existing studies}

In the field of transportation, there are several similar approaches such as the life cycle approach, the life course (or life trajectory or life event) approach, and the lifestyle approach.

The life cycle approach describes the birth-to-death sequence of stages in the life of an individual or a family (Zimmerman, 1982). Fried et al. (1977) made an initial attempt to identify life cycle status as one of the major determinants of the trajectory of travel behavior adaptations, together with major changes in residential or work location. A recent study revealed that latent modal preferences are strongly correlated with life cycle characteristics (Vij et al., 2013).

Applications of life course research are based on the idea that people's travel behavior can be explained by its continuity over a lifetime and by specific life events (Lanzendorf, 2003). Van der Waerden et al. (2003) investigated the influence of key life events on travel mode choice switching behavior. Recently, Oakil (2013) examined temporal dependence in life trajectories and mobility decisions, focusing on commuting mode choice. Scheiner and Holz-Rau (2013) provided an excellent review covering major literature in this context.

Salomon and Ben-Akiva (1983) applied the concept of lifestyle to classify shoppers who chose travel mode and destination based on their roles as a household member, a worker, and a consumer of leisure. Chliaoutakis et al. (2005) identified major lifestyle factors based on the frequency of participation in activities. In estimating a residential location choice model, Walker and $\mathrm{Li}$ (2007) identified three lifestyle groups: suburban dwellers, urban dwellers and transit-riders. Even though the lifestyle approach recognizes the interdependences among life choices, lifestyle variables have been treated as exogenous factors in explaining residential and travel behavior.

In summary, existing studies commonly assume the life cycle, life event and/or lifestyle variables affect residential and travel behavior. In contrast, the life-oriented approach deals with two-way relationships 
between residential/travel behavior and other life domains. From the perspective of transport policy, it captures the effects of policy implementation in the form of both policy outputs (e.g., mode choice) and policy outcomes (e.g., influence on other life choices and the resulting QOL). However, existing approaches only care about the policy outputs.

\section{$3 \quad$ Revisiting residential self-selection issues}

Here, residential self-selection issues are revisited focusing on the eight major life domains (except travel behavior) described in the previous section.

1. The residence domain. I will not discuss further the residential self-selection issues from the residence domain perspective because various existing studies (e.g., Mokhtarian and Cao, 2008; Cao et al., 2009; Van Wee, 2009) have already addressed the issues well.

2. The job domain. Van Wee (2009) discussed the residential self-selection issues related to the job domain from three aspects: work location, employment characteristics, and job type. People whose job requires more travel to other cities may choose to reside in a transit-convenient residential area.

3. The family budget domain. Pinjari et al. (2007) argued that "households and individuals may locate themselves into neighborhoods that allow them to pursue their activities using modes that are compatible with their socio-demographics (e.g., income).” For example, low-income people may self-select themselves to live in a place close to transit stations because they cannot afford to purchase a car and therefore they cannot choose to live in a car-dependent residential area. It is also relevant how income is spent; however, no study has been undertaken from such a perspective.

4. The health domain. A growing literature has shown that built environment characteristics such as walkability (Ewing et al., 2006; Frank et al., 2007; Dyck et al., 2011) and availability of recreation centers (Gordon-Larsen et al., 2006; Diez Roux et al., 2007) are associated with active travel. Those who pursue physical fitness and are bicycling inclined may self-select themselves to reside in neighborhoods with good bicycling facilities that allow them to participate in bicycling activities (Pinjari et al., 2009). When health is considered in travel choices, the activitybased approach may not work well to explain health-conscious travel choices. In this case, travel for its own sake and travel for utilitarian purposes should be distinguished from each other (Mokhtarian and Salomon, 2001; Mokhtarian et al., 2001; Ory and Mokhtarian, 2005). Cao et al. (2006a) confirmed that pedestrian shopping trips were more likely to be explained by residential self-selection.

5. The neighborhood domain. In the famous "Three Character Classic" in China (or "San Zi Jing" in Chinese, probably written in the 13th century), there is one phrase, "of old, the mother of Mencius chose a neighborhood." It is said that Mencius's mother changed residences three times in order to find better neighbors to influence Mencius's learning behavior. This ancient saying is still applicable in the contemporary context. It not only suggests that children's education is influenced by their social environment, but also suggests that choice of residential area is influenced by the neighborhood environment.

Residential segregation is a common social phenomenon mainly in the USA and some European countries, which sorts populations into different residential areas based on race, ethnicity, income, etc. Furthermore, studies of social environment or social influence are also relevant to this discussion. Páez and Scott (2007) clarified the social influence on travel behavior within 
the context of telecommuting. Walker et al. (2011) confirmed that an individual's mode choice to work is influenced by the choices made by one's peers, friends, family, and neighbors.

6. The education and learning domain. Households that attach more importance to children's education and learning may choose to live in places close to better schools with better living environments, which may be occasionally located close to a transit-convenient residential area. As stated by Lankford and Wyckoff (2006), households select consumption bundles of neighborhood, community and local public amenities through residential location. They jointly represented choices of school and residence locations, where the influence of the self-selection of families into communities was incorporated.

7. The family life domain. Bhat and Guo (2007) argued that "households with small children might locate in neighborhoods with easy-to-access park facilities and pursue several nonmotorized recreation trips to nearby parks." The altruism of Mencius's mother is relevant to this domain. Some studies explored the influence of interpersonal interactions in the context of time use behavior (e.g., Zhang et al., 2002; Zhang and Fujiwara, 2006).

8. The leisure and recreation domain. Health-related studies reveal that access to recreation facilities and the aesthetics of activity settings are related to walking (Owen et al., 2004; WHO, 2004). Those who want to enjoy their social life may self-select themselves to reside in residential areas with high population density, which means that transit services are provided in a more convenient way. However, little can be found with respect to relevant studies about leisure and recreation.

\section{$4 \quad$ Empirical evidence of behavioral interdependences}

The above review suggests that those who have specific life choice behaviors may self-select themselves to reside in a specific type of residential area, consequently leading to specific travel behavior. In other words, the self-selection may come from the influence of people's other life choice behavior. I provide two case studies to show the relevant evidence.

\subsection{Cross-sectional evidence}

I used data from the life choice survey described in Section 2.1.1. The survey was implemented by recruiting respondents whose age and gender distributions were consistent with those of the population in different types of cities in Japan with the assistance of a major Japanese Internet survey company, which had 1.4 million registered survey panels at the time of survey. As a result, 1,552 respondents aged between 15 and 69 years participated in the survey.

In the nine life domains, a total of 114 behavior variables were included, some or all of which might not be independent of each other. To clarify statistically the potential interdependences among these variables, an exhaustive Chi-square Automatic Interaction Detector (CHAID) analysis approach (Biggs et al., 1991) was used. The CHAID can find the best split for each predictor variable, as one of the most popular methods for classification or segmentation. It automatically builds a series of "if-then" rules (in the form of a decision tree) based on the given data.

Table 1 shows how each of the 32 behavior variables is influenced by the 113 variables, where only statistically significant variables are included. Four variables describe the residential behavior, i.e., residence duration, number of stories of residence, total living area, and number of rooms. As for travel behavior, there are four vehicle ownership variables, 11 travel mode variables (car or other modes), and one transportation and communication expenditure variable. Other travel-related variables include various time use variables (mainly length of time and frequency). 
Here, I selected 32 variables from eight life domains and excluded the travel behavior domain because existing studies have already clarified the influence of some life choice aspects on it.

Table 2 summarizes how each life domain as a whole is explained by other domains. For example, there are four residential variables and 12 family budget variables. As shown in Table 1, a total of 10 family budget variables significantly affect the four residential variables, indicating that 20.8 percent $(=10 /(4 \times 12))$ of the family budget variables affect the residence domain. The value 20.8 percent is shown in the cell at the intersection of the second row and the third column in Table 2. Other percentages in Table 2 are calculated in the same way. Among the 56 pairs of eight life domains, 11 pairs are independent of each other and 45 pairs are statistically interdependent.

Decisions in the residence domain are most strongly associated with the neighborhood domain since 38 percent of the behavior variables in the neighborhood domain affect decisions in the residence domain, which is the highest among the other seven domains. The life domain that is most strongly influenced by the residence domain is the family budget domain, where 17 percent of the variables in the residence domain are statistically influential. Contrary to our expectation, the residence domain does not affect the education and learning domain.

As for the influence of travel behavior on other life domains, vehicle ownership is influential for the family budget, health, and leisure and recreation domains. Expenditure on transportation and communication affects only the residence domain. Commuting mode influences the residence, education and learning, and leisure and recreation domains. Travel mode choices for leisure and recreation affect the residence, education and learning, and family life domains. Analysis revealed that travel mode choices of the education and learning domain do not show any influence on the other domains. Note that the within-domain influence of travel behavior is ignored in the analysis.

Health issues are always at the core of discussions about the relationship between residential choice and travel behavior. Table 2 reveals that the most influential life domain for the health domain is the job domain $(20 \%)$, followed by the residence domain $(9 \%)$ and the leisure and recreation domain $(5 \%)$. The other four domains are not influential at all.

The behavioral interdependences across life domains suggest that ignoring the roles of other life domains in the analysis of residential choice and travel behavior may result in seriously biased inferences about residential self-selection and may produce misleading policy implications. Accordingly, surveys of residential choice and travel behavior should include the information of major life domains in order to enhance the reliability and robustness of policy suggestions. 
Table 1. Behavioral interdependences and mutual predictions across life domains

\begin{tabular}{|c|c|c|c|}
\hline Life domain & Target behavior variables & Predictors of target behavior variables (Appearance order in the decision tree) & Prediction accuracy \\
\hline \multirow[t]{4}{*}{ Residence } & Residence duration & $\begin{array}{l}\text { Residential expenses; education and learning expenses; frequency of neighborhood communication; frequency of visiting friends, } \\
\text { families and relatives (domestic travel); participation in community activities; discretionary activity time on weekends and holidays; } \\
\text { distance from home to and activity time at neighboring park and amusement park; income; out of home activity time with family } \\
\text { on weekends and holidays. }\end{array}$ & $28.3 \%$ \\
\hline & Number of stories of residence & $\begin{array}{l}\text { Distance from home to cinema and theater; frequency of neighborhood communication; final academic degree; travel modes to } \\
\text { cinemas and work-place; in-home activity time with family on weekends and holidays; frequency of visiting friends, families and } \\
\text { relatives (domestic travel). }\end{array}$ & $5.7 \%$ \\
\hline & Number of rooms & $\begin{array}{l}\text { Transportation and communication expenses; expenses on electricity, heating and water; income; in-home activity time with family } \\
\text { on weekdays; activity time of sports; final academic degree; experience of serious accidents and illness; discretionary activity time } \\
\text { on weekends and holidays. }\end{array}$ & $3.6 \%$ \\
\hline & Total living area & $\begin{array}{l}\text { Furniture expenses; distance from home to facility for foreign language learning; in-home activity time with family on weekdays; } \\
\text { residential expenses; income; education and learning expenses. }\end{array}$ & $1.2 \%$ \\
\hline Family budget & Income & $\begin{array}{l}\text { Total living area; activity time with family; distance to sports facility; employment duration; rental house; paid holidays; distance } \\
\text { from home to nearest station; frequency of one-day trips; expenses on domestic travel; number of medium-sized cars owned. }\end{array}$ & $43.3 \%$ \\
\hline $\begin{array}{l}\text { Health } \\
\text { condition }\end{array}$ & Sleeping time & $\begin{array}{l}\text { Paid holidays; discretionary activity time on weekdays; frequency of Internet usage; number of small-sized cars owned; distance } \\
\text { from home to secondary school. }\end{array}$ & $10.0 \%$ \\
\hline \multirow[t]{2}{*}{$\begin{array}{l}\text { Neighborhood } \\
\text { communication }\end{array}$} & Participation in community activities & $\begin{array}{l}\text { House ownership; communication frequency with relatives; education and learning expenses; distance from home to nearest bus } \\
\text { stop; time of gentle physical exercise; final academic degree; activity time at park and amusement park. }\end{array}$ & $47.1 \%$ \\
\hline & $\begin{array}{l}\text { Frequency of neighborhood } \\
\text { communication }\end{array}$ & $\begin{array}{l}\text { In-home and out-of-home activity time with family on weekdays; total living area; frequency of gentle physical exercise; house } \\
\text { ownership; ownership of detached house; education and learning expenses; residence duration; communication frequency with } \\
\text { relatives. }\end{array}$ & $40.3 \%$ \\
\hline \multirow[t]{4}{*}{$\begin{array}{l}\text { Education \& } \\
\text { Learning }\end{array}$} & $\begin{array}{l}\text { Learning frequency: English and } \\
\text { other foreign languages }\end{array}$ & $\begin{array}{l}\text { Frequency of strenuous exercise with body contact (e.g., soccer and basket ball); frequency of visiting cinema and theather; travel } \\
\text { mode (car or not) to sports facility; expenses on visiting friends, families and relatives (domestic travel). }\end{array}$ & $88.9 \%$ \\
\hline & $\begin{array}{l}\text { Frequency of general education: } \\
\text { society, natural science, household } \\
\text { management, etc }\end{array}$ & $\begin{array}{l}\text { Frequency of strenuous exercise with body contact (e.g., soccer and basket ball); frequency of visiting cinema and theater; } \\
\text { frequency of gentle physical exercise; discretionary activity time on weekends and holidays; activity time at park and amusement } \\
\text { park; frequency of playground usage; expenses on residence and clothes. }\end{array}$ & $87.0 \%$ \\
\hline & $\begin{array}{l}\text { Frequency of hobby learning: } \\
\text { culture, arts, etc. }\end{array}$ & $\begin{array}{l}\text { Frequency of gentle physical exercise; frequency of park and amusement park usage; distance from home to facility of gentle } \\
\text { physical activities; expenses on one-day trips; frequency of neighborhood communication; frequency and time use of visiting } \\
\text { cinema and theater. }\end{array}$ & $74.3 \%$ \\
\hline & $\begin{array}{l}\text { Frequency of job-related learning: } \\
\text { PC, care-giving, etc. }\end{array}$ & $\begin{array}{l}\text { Frequency of strenuous exercise with body contact (e.g., soccer and basket ball); commuting mode (car or not); frequency of one- } \\
\text { day trips; expenses on visiting friends, families and relatives; experience of serious accidents and illness; communication frequency } \\
\text { with relatives; activity time of sports; distance from home to facility of gentle physical exercise. }\end{array}$ & $71.5 \%$ \\
\hline \multirow[t]{3}{*}{ Employment } & Employment duration & Income; expenses on one-day trips; residence duration; ownership of detached house & $11.7 \%$ \\
\hline & Working days & Discretionary activity time on weekdays; frequency of dinner with family; in-home activity time with family on weekdays. & $7.7 \%$ \\
\hline & Actual paid holidays & Income; distance from home to cinema; activity time of sports; final academic degree; ownership of detached house. & $4.5 \%$ \\
\hline \multirow[t]{6}{*}{ Family life } & Frequency of dinner with family & $\begin{array}{l}\text { Number of rooms; working days; expenses on domestic travel; ownership of detached house; final academic degree; discretionary } \\
\text { activity time on weekdays; expenses on cultural learning and recreational activities; number of stories of residence; frequency of } \\
\text { playground usage; sleeping time. }\end{array}$ & $76.7 \%$ \\
\hline & $\begin{array}{l}\text { In-home activity time with family } \\
\text { on weekends and holidays }\end{array}$ & $\begin{array}{l}\text { Total living area; paid holidays; house ownership; distance from home to elementary school; discretionary activity time on } \\
\text { weekday; distance from home to post office and bank; expenses on domestic travel. }\end{array}$ & $58.0 \%$ \\
\hline & $\begin{array}{l}\text { Communication frequency with } \\
\text { relatives }\end{array}$ & $\begin{array}{l}\text { Frequency of neighborhood communication; frequency of one-day trips; income; activity time of gentle physical exercise; } \\
\text { frequency of domestic travel; frequency of visiting friends, families and relatives; ownership of detached house; food expenses. }\end{array}$ & $36.0 \%$ \\
\hline & $\begin{array}{l}\text { In-home activity time with family } \\
\text { on weekdays }\end{array}$ & $\begin{array}{l}\text { Working days; paid holidays; number of rooms; discretionary activity time on weekdays; frequency of one-day trips; final } \\
\text { academic degree; job-related activity time; activity time of strenuous exercise with body contact (e.g., soccer and basket ball); } \\
\text { expenses on visiting friends, families and relatives; frequency of visiting cinema and theater; activity time at park and theater. }\end{array}$ & $19.2 \%$ \\
\hline & $\begin{array}{l}\text { Out-of-home activity time with } \\
\text { family on weekends and holidays }\end{array}$ & $\begin{array}{l}\text { Frequency of one-day trips; travel mode (car or not) to park amusement park and playground; experience of serious accidents and } \\
\text { illness; residence duration; income; number of rooms; discretionary activity time on weekends. }\end{array}$ & $9.3 \%$ \\
\hline & $\begin{array}{l}\text { Out-of-home activity time with } \\
\text { family members on weekdays }\end{array}$ & $\begin{array}{l}\text { Frequency of neighborhood communication; frequency of hobby activities; activity time at park and theather; house ownership; } \\
\text { discretionary activity time on weekdays; final academic degree; distance from home to cinema. }\end{array}$ & $4.7 \%$ \\
\hline \multirow[t]{11}{*}{$\begin{array}{l}\text { Leisure \& } \\
\text { Recreation }\end{array}$} & $\begin{array}{l}\text { Frequency of enjoying horse and } \\
\text { bicycle racing }\end{array}$ & $\begin{array}{l}\text { Frequency of gentle physical exercise; rental house; employment duration; frequency of dinner with family; final academic degree; } \\
\text { experience of serious accidents and illness; activity time of strenuous exercise without body contact (e.g., jogging and badminton). }\end{array}$ & $93.7 \%$ \\
\hline & Frequency of Internet usage & $\begin{array}{l}\text { Sleeping time; job-related learning time; final academic degree; distance from home to facility of gentle physical exercise; house } \\
\text { ownership; number of medium-sized cars owned; rental house; distance from home to city hall; frequency of participating in } \\
\text { community activitites. }\end{array}$ & $75.7 \%$ \\
\hline & Frequency of sports activities & $\begin{array}{l}\text { Frequency of strenuous exercise without body contact (e.g., jogging and badminton); frequency of gentle physical exercise; } \\
\text { working days; distance from home to facility of strenuous exercise with body contact (e.g., soccer and basket ball); food expenses. }\end{array}$ & $75.6 \%$ \\
\hline & $\begin{array}{l}\text { Frequency of exercise on } \\
\text { playgrounds }\end{array}$ & $\begin{array}{l}\text { Frequency of strenuous exercise with body contact (e.g., soccer and basket ball); emplolyment duration; distance from home to } \\
\text { facility of gentle physical exercise; house onwershipl; education expenses; distance from home to facility of foreign language } \\
\text { learning; rental house. }\end{array}$ & $68.6 \%$ \\
\hline & $\begin{array}{l}\text { Frequency of visiting cinemas and } \\
\text { theaters }\end{array}$ & $\begin{array}{l}\text { Frequency of hobby learning, frequency of gentle physical exercise; frequency and activity time of strenuous exercise without body } \\
\text { contact (e.g., jogging and badminton); furniture expenses; frequency of dinner with family. }\end{array}$ & $60.3 \%$ \\
\hline & $\begin{array}{l}\text { Frequency of park and amusement } \\
\text { park usage }\end{array}$ & $\begin{array}{l}\text { Frequency of strenuous exercise without body contact (e.g., jogging and badminton); time of hobby learning; out-of-home activity } \\
\text { time with family on weekdays and holidays; number of stories of residence; residence duration; travel mode (car or not) to work- } \\
\text { place; activity time of strenuous exercise with body contact (e.g., soccer and basket ball). }\end{array}$ & $59.1 \%$ \\
\hline & Discretionary time on weekdays & $\begin{array}{l}\text { Working days; in-home and out-of-home activity time with family on weekends and holidays; paid holidays; expenses on other } \\
\text { purposes; residence duration; education and learning expenses; distance from home to kindergarden; expenses on health and } \\
\text { medical care. }\end{array}$ & $21.2 \%$ \\
\hline & Discretionary time on weekends & $\begin{array}{l}\text { In-home and out-of-home activity time with family on weekends and holidays; frequency of participating in community activities; } \\
\text { residence expenses; number of rooms; residence duration. }\end{array}$ & $12.2 \%$ \\
\hline & One-day trips on holiday & $\begin{array}{l}\text { Out-of-home activity time with family on weekends and holidays; frequency of strenuous exercise without body contact (e.g., } \\
\text { jogging and badminton); number of stories of residence; number of small-sized cars owned; rental house; ownership of detached } \\
\text { house; distance from home to hobby facility; residence duration; frequency of neighborhood communication. }\end{array}$ & $10.3 \%$ \\
\hline & Frequency of domestic travel & $\begin{array}{l}\text { Frequency of gentle physical exercise; out-of-home activity time with family on weekends and holidays; education and recreation } \\
\text { expense; activity time of strenuous exercise without body contact (e.g., jogging and badminton); final academic degree; job-related } \\
\text { activity time; income; total living area; ownership of detached house. }\end{array}$ & $10.0 \%$ \\
\hline & Frequency of overseas travel & $\begin{array}{l}\text { Frequency of foreign language learning, number of stories of residence; ownership of detached house; house ownership; final } \\
\text { academic degree; frequency of gentle physical exercise; expenses on cultural learning and recreational activities; residence duration. }\end{array}$ & $5.8 \%$ \\
\hline
\end{tabular}


Table 2. Summary of mutual predictions and behavioral interdependences across life domains

\begin{tabular}{|l|r|r|r|r|r|r|r|r|}
\hline $\begin{array}{l}\text { Domain } \\
\text { Target life domain }\end{array}$ & Residence & Family budget & Health & Neighborhood & $\begin{array}{l}\text { Education \& } \\
\text { learning }\end{array}$ & Employment & Family life & $\begin{array}{l}\text { Leisure \& } \\
\text { recreation }\end{array}$ \\
\hline Residence & & $20.8 \%$ & $2.3 \%$ & $37.5 \%$ & $4.4 \%$ & $5.0 \%$ & $16.7 \%$ & $6.6 \%$ \\
\hline Family budget & $17.4 \%$ & & $0.0 \%$ & $0.0 \%$ & $0.0 \%$ & $40.0 \%$ & $16.7 \%$ & $7.9 \%$ \\
\hline Health & $8.7 \%$ & $0.0 \%$ & & $0.0 \%$ & $0.0 \%$ & $20.0 \%$ & $0.0 \%$ & $5.3 \%$ \\
\hline Neighborhood & $13.0 \%$ & $8.3 \%$ & $9.1 \%$ & & $2.9 \%$ & $0.0 \%$ & $33.3 \%$ & $1.3 \%$ \\
\hline Education \& learning & $0.0 \%$ & $4.2 \%$ & $18.2 \%$ & $12.5 \%$ & $-2 \%$ & $5.0 \%$ & $4.2 \%$ & $9.2 \%$ \\
\hline Employment & $4.3 \%$ & $5.6 \%$ & $0.0 \%$ & $0.0 \%$ & $2.0 \%$ & & $11.1 \%$ & $3.5 \%$ \\
\hline Family life & $8.7 \%$ & $6.9 \%$ & $6.1 \%$ & $16.7 \%$ & $4.9 \%$ & $13.3 \%$ & $5.8 \%$ \\
\hline Leisure \& recreation & $9.5 \%$ & $7.6 \%$ & $15.7 \%$ & $13.6 \%$ & $5.3 \%$ & $10.9 \%$ & $13.6 \%$ & \\
\hline
\end{tabular}

\subsection{Life-course evidence}

I used data from the life history survey explained in Section 2.1.2. The survey was implemented in November 2010 with the assistance of the same Internet survey company mentioned above. The observed period in the survey differs according to respondents' age (i.e., from the year when respondents were 18 years old to 2010). In the data, the oldest respondents were 69 years old and a total of 52 years were covered (1959-2010). I carried out an exhaustive CHAID analysis to understand people's mobility behavior during the life course as well as the interactions between different types of mobilities, focusing on the occurrence times of mobilities in each biography. I summarize major findings below. Details refer to Zhang et al. (2013).

Residential mobility in a year is mostly influenced by household structure mobility and employment/education mobility in the same year, followed by the residential mobilities experienced in the 25 years prior to the target year and in the following 10 years. Residential mobility is also largely related to the experiences in the previous 25 years and to the plan in the following five years with respect to the household structure biography. Obvious influences are observed from the education/employment biography during the previous 25 years and the next 10 years, as well as the car ownership biography during the past 10 years and some way into the future (the next five years). Compared with education/employment and car ownership biographies, the household biography has more influence on residential mobility. The most important predictor of car ownership mobility is the car ownership plan made 5 years later after the target year. Past experience in the car ownership biography and the mobilities in the household structure, employment/education and residential biographies in the target year are also relevant. Concerning the influence of past experience and future plans on other biographies, substantial interdomain state dependence and future expectations are identified, with a wide span ranging from 20 or 25 years prior to the target year to 10 years after the target year in residential, household structure, and education/employment biographies. Furthermore, car ownership mobility is more sensitive to the impact of residential mobility than the mobilities observed in the domains of household structure and employment/education.

In summary, the results reveal the existence of both intradomain and interdomain state dependence and future expectations in both the short term and the long term. It is also true that such dynamics are complex in that there are no consistent trends with respect to the time period. These findings suggest the necessity of developing biographical interdependence models with flexible structures that capture the influences of state dependence and future expectations within and across domains over different time scales in the life course in a unified framework. 


\section{Challenges of the life-oriented approach for analysis of residential self-selection}

Many aspects of life choices may be closely linked with urban and transportation policies. However, it is not easy to ask respondents to answer many questions at the same time. It is therefore important to ensure that various behavioral aspects are packaged well for practical use. Thus, it is necessary to understand how much each life domain can be predicted (or imputed) by other domains. My mutual predictions were shown in the third column of Table 1 . The findings are summarized below.

1. The prediction accuracy of the education and learning domain by the other domains ranges between 72 percent and 89 percent, which are highest among all the domains, implying that the education and learning domain can be fairly well imputed by the other domains.

2. The prediction accuracy of the job, health and residence domains is somewhat lower (mostly lower than 10 percent), suggesting that they must be directly surveyed. In other words, survey packaging should be done with these domains as core parts.

3. The family budget, which is usually most difficult to obtain, can be predicted by other domains with an accuracy of 43 percent. This suggests that the family budget may be well predicted by making full use of the information obtained from other domains.

4. The prediction accuracy of the family life domain varies considerably: 5 percent-19 percent for the activity time with family, and 36 percent -77 percent for the other variables.

5. As for the leisure and recreation domain, 55 percent of variables can be predicted with an accuracy higher than 60 percent. However, the prediction accuracy of the remaining variables is only about 10 percent. For such a domain, the packaging should be done with respect to a group of variables, not the whole set of variables in the domain.

6. It can be seen that the prediction accuracy is not proportional to the number of domain variables. This may mean that increasing the prediction accuracy should be done by properly selecting domain variables rather than just simply increasing them.

Note that the above results may be strongly context dependent and analyses in different countries may derive different mutual predictions.

Although the concept of life choice was not explicitly introduced in existing studies, some life choice aspects have been investigated in the form of socio-demographic attributes (e.g., income and expenditure, number of children, education level) and neighborhood variables (e.g., commuting distance, distance from educational facilities) (Boarnet and Sarmiento, 1998; Cao et al., 2006b; Cao, 2013; Van Wee, 2009). These studies have two major shortcomings. First, life choice variables have been treated as explanatory variables, which may lead to modeling misspecification. Second, many life choice aspects have been omitted. Since omitting important variables may cause serious model estimation biases and give misleading policy implications, the influence of life choices on the analysis of residential self-selection should be reflected in a more systematic way.

The residential self-selection issue should be reexamined by extending the decision boundary (Figure 1). Based on the life-oriented approach, I suggest adding life choices as additional decision variables into the original framework. In the new framework (Figure 2), life choices become the third source of the selfselection and more importantly, dynamic interdependences between residential choice (RC), travel behavior (TR), and other life choices (OLC) should be properly modeled. Challenges may include: (1) how to add decisions on OLC into the existing framework; (2) how to incorporate the influence of unobserved factors; (3) how to represent future expectations; and (4) how to specify behavioral dynamics over a longer time period. 


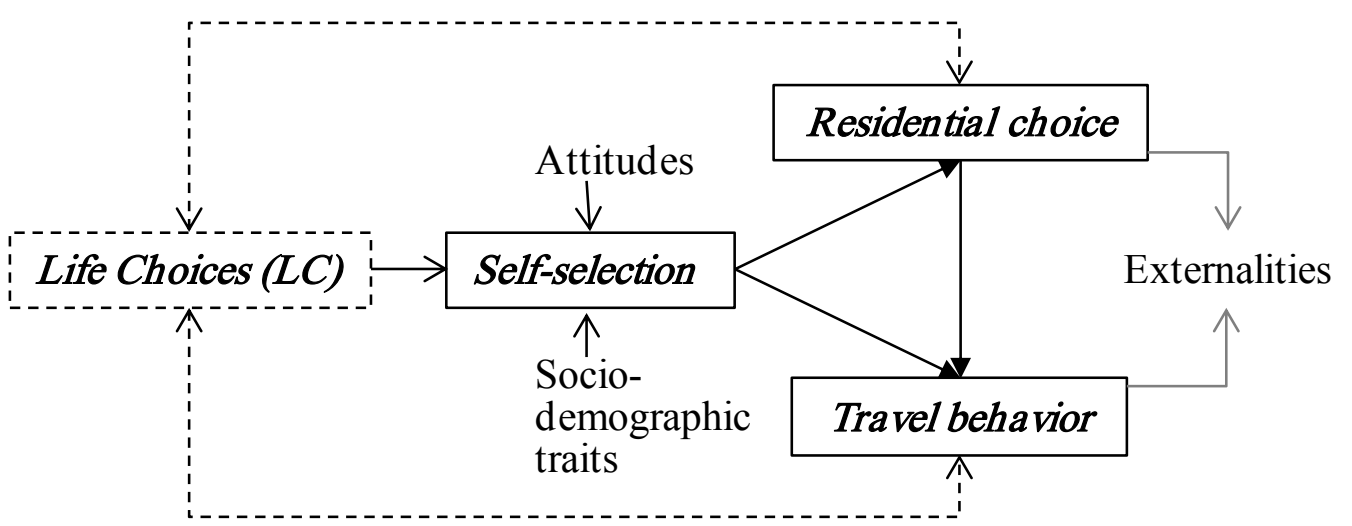

(a) Static version

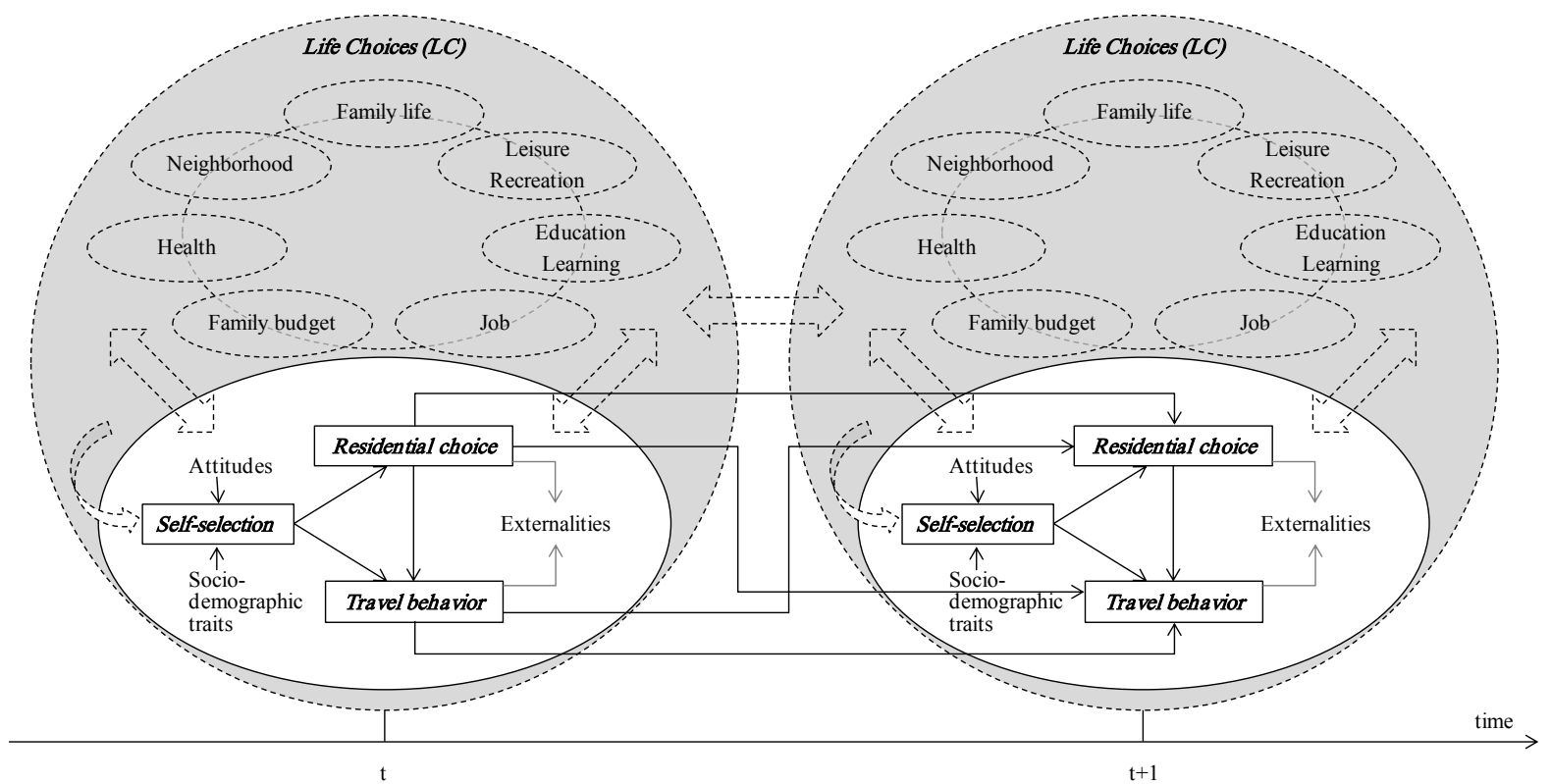

(b) Dynamic version

Figure 2. A new framework for the analysis of residential self-selection

As for the first challenge, one may simply build up OLC models and estimate them together with RC-TB models. For example, Yu et al. (2012) developed a joint mixed multinomial logit and multiple discrete-continuous extreme value model to represent multiple self-selection effects caused by residential location choices on household energy consumption behavior (represented by ownership and usage of both in-home appliances and out-of-home cars). Such a modeling approach may be also applicable to represent the residential self-selection caused by OLC.

Regarding the second challenge, models with both discrete and continuous choices as well as more flexible error structures are required. Zhang et al. (2012a) developed an integrated model of tourists' time use and expenditure behavior and destination visit behavior based on the concept of self-selection and a Frank-type fully nested Archimedean copula. The copula approach may be extended to represent the residential self-selection issues by jointly modeling other life choices.

The influence of future expectations on residential and travel behavior has received limited attention from both survey and modeling perspectives. Among the limited number of studies, Zhang et al. (2004), 
Kuwano et al. (2011), and Wang et al. (2010) investigated the impacts of future expectations on travel mode choice and vehicle type choice based on a dynamic generalized extreme value (DGEV) model proposed by (Swait et al., 2000). On the other hand, it has been relatively long recognized in other disciplines (e.g., psychology and economics) that people's numerous behaviors are forward looking (e.g., Kuklinski and West, 1981; Manski, 1999; Carvajal et al., 2000; Chan and Stevens, 2004; Khan and Dhar, 2007; Van der Klaauw and Wolpin, 2008; Van der Klaauw, 2012). Unrevealed issues include how far people look forward in deciding their current behavior, how people form their expectations toward future behavior, whether future expectations are stable over time or not, how reliable are people's reporting about future expectations, etc. Innovative survey methods should be developed to answer these questions.

Concerning the fourth challenge, Heckman's (1981) dynamic choice modeling framework may be applicable. In fact, the above DGEV-based applications also incorporate the influence of state dependence over about 10 years, which is in line with Heckman's idea. It is, however, unclear whether the approach can be extended to deal with a much longer time period. The aforementioned studies are related to a within-domain analysis. Expanding these studies to perform between-domain analysis may result in more complexities in representing the dynamic interdependences, which requires more efforts for a better understanding of residential self-selection.

Moreover, life choices also include various interrelated behavioral aspects. Different types of life decisions are made over different time scales and involve different types of decision makers, whose roles further vary over time. In particular, when looking at life choices over the life course, some independent variables (e.g., job, work place, and household composition) in conventional models may become dependent variables. All these behavioral issues are required to be properly modeled. While Section 4 has provided relevant evidence of the needs of representing life choices, it is still premature to draw any sound conclusions about how to simultaneously incorporate dynamic interdependences between life choices. More efforts should be accumulated based on both statistically and behaviorally oriented approaches.

\section{Conclusion}

Insights have been accumulated via various studies of residential self-selection. However, many existing arguments and findings may only hold under the local decision context. The relevance of people's life choice (i.e., the global decision) to residential self-selection issues, and limited studies, suggest that we have just scratched the surface of the whole sphere and must make efforts to achieve more robust conclusions to support actual policy decisions on the integration of land use and transportation systems. This study proposed a life-oriented approach to reexamine the issues of residential self-selection by explicitly and systematically incorporating various behavioral interdependences across a broader set of life domains over time. Several challenges are clarified. First, innovative transdisciplinary approaches are required for a better understanding of complex life choice phenomena. Implementing travel diary surveys and especially activity diary surveys is already a difficult task in practice. Including more life choice questions into existing surveys will undoubtedly make practical applications more difficult. To tackle this problem, various life choice aspects should be properly packaged. Different sets of behavioral data from the packaged surveys should be logically combined by reflecting behavioral mechanisms based on knowledge and insights from different disciplines, rather than just focusing on statistical relationships. Using the packaged surveys, integrated behavior models covering various life domains should be developed by reflecting dynamic behavioral decision-making mechanisms to support policy decisions based on more scientific evidence. It is expected that the life-oriented approach could pave a new way for further exploring the issues of residential self-selection. 


\section{$7 \quad$ Acknowledgements}

This research was supported by the Grants-in-Aid for Scientific Research (A) (No.22246068) of the Japan Society for the Promotion of Science (JSPS), Japan.

\section{References}

Abou-Zeid, M., Witter, R., Bierlaire, M., Kaufmann V., and Ben-Akiva, M. 2012. Happiness and travel mode switching: Findings from a Swiss public transportation experiment. Transport Policy 19 (1): 93-104. http://dx.doi.org/10.1016/j.tranpol.2011.09.009

Beige, S., and Axhausen, K.W. 2008. Long-term and mid-term mobility decisions during the life course - Experiences with a Retrospective Survey -. IATSS Research 32 (2): 16-33.

Bhat, C.R., and Guo, J.Y. 2007. A comprehensive analysis of built environment characteristics on household residential choice and auto ownership levels. Transportation Research Part B 41: 506-526.

Biggs, D., De Ville, B., Suen, E. 1991. A method of choosing multiway partitions for classification and decision trees. Journal of Applied Statistics 18 (1): 49-62. http://dx.doi.org/10.1080/02664769100000005

Boarnet, M.G., and Sarmiento, S. 1998. Can land use policy really affect travel behaviour? A study of the link between non-work travel and land-use characteristics. Urban Studies 35 (7): 1155-1169. http://dx.doi.org/10.1080/0042098984538

Cao, J. 2013. The association between light rail transit and satisfactions with travel and life: evidence from Twin Cities. Transportation 40 (5): 921-933. http://dx.doi.org/10.1007/s11116-013-9455-8

Cao, X., Handy, S.L., and Mokhtarian, P.L. 2006(a). The influences of the built environment and residential self-selection on pedestrian behavior: evidence from Austin, TX. Transportation 33: 1-20. http://dx.doi.org/10.1007/s11116-005-7027-2

Cao, X., Mokhtarian, P.L., and Handy, S.L. 2006(b). Neighborhood design and vehicle type choice: evidence from Northern California. Transportation Research Part D 11: 133-145. http://dx.doi.org/10.1016/j.trd.2005.10.001

Cao, X., Mokhtarian, P.L. , and Handy, S.L. 2009. The relationship between the built environment and nonwork travel: a case study of Northern California. Transportation Research Part A 43: 548-559. http://dx.doi.org/10.1016/j.tra.2009.02.001

Carvajal, M.J., Bendana, D., Bozorgmanesh, A., Castillo, M., Pourmasiha, K., Rao, P., and Torres, J. 2000. Inter-gender differentials between college students' earnings expectations and the experience of recent graduates. Economics of Education Review 19(3): 229-243. http://dx.doi.org/10.1016/S0272-7757(99)00034-5

Chan, S., and Stevens, A.H. 2004. Do changes in pension incentives affect retirement? A longitudinal study of subjective retirement expectations. Journal of Public Economics 88(7-8): 1307-1333. http://dx.doi.org/10.1016/S0047-2727(02)00223-2

Chliaoutakis, J. E., Koukouli, S., Lajunen, T., and Tzamalouka, G. 2005. Lifestyle traits as predictors of driving behaviour in urban areas of Greece. Transportation Research Part F 8(6): 413-428. http://dx.doi.org/10.1016/j.trf.2005.05.003

Cole, R., Burke, M., Leslie, E., Donald, M., and Owen, N. 2010. Perceptions of representatives of public, private, and community sector institutions of the barriers and enablers for physically active transport. Transport Policy 17: 496-504. http://dx.doi.org/10.1016/j.tranpol.2010.05.003

De Hollander, A.E.M., and Staatsen, B.A.M. 2003. Health, environment and quality of life: an epidemiological perspective on urban development. Landscape and Urban Planning 65: 53-62. http://dx.doi.org/10.1016/S0169-2046(02)00237-2

Delmelle, E.C., Haslauer, E., and Prinz, T. 2013. Social satisfaction, commuting and neighborhoods. Journal of Transport Geography 30: 110-116. http://dx.doi.org/10.1016/j.jtrangeo.2013.03.006 
Diez Roux, A.V., Evenson, K.R., McGinn, A.P., Brown, D.G., Moore, L., Brines, S., and Jacobs, D.R. Jr. 2007. Availability of recreational resources and physical activity in adults. American Journal of Public Health 97: 493-499. http://dx.doi.org/10.2105/AJPH.2006.087734

Dyck, D.V., Cardon, G., Deforche, B., Owen N., and De Bourdeaudhuij, I. 2011. Relationships between neighborhood walkability and adults' physical activity: how important is residential selfselection?. Health \& Place 17: 1011-1014. http://dx.doi.org/10.1016/j.healthplace.2011.05.005

Ewing, R., Brownson, R.C., and Berrigan, D. 2006. Relationship between urban sprawl and weight of United States youth. American Journal of Preventive Medicine 31: 464-474. http://dx.doi.org/10.1016/j.amepre.2006.08.020

Frank, L., Kerr, J., Chapman, J., and Sallis, J. 2007. Urban form relationships with walk trip frequency and distance among youth. American Journal of Health Promotion 21: 305-311. http://dx.doi.org/10.4278/0890-1171-21.4s.305

Fried, M., Havens, J., and Thall, M. 1977. Travel Behavior - A Synthesized Theory. National Cooperative Highway Research Program, Transportation Research Board, National Research Council, Project 814 Final Report, 145 pages.

Frisvold, D., and Golberstein, E. 2011. School quality and the education-health relationship: Evidence from Blacks in segregated schools. Journal of Health Economics 30 (6): 1232-1245. http://dx.doi.org/10.1016/j.jhealeco.2011.08.003

Gordon-Larsen, P., Nelson, M.C., Page, P., and Popkin, B.M. 2006. Inequality in the built environment underlies key health disparities in physical activity and obesity. Pediatrics 117: 417-424. http://dx.doi.org/10.1542/peds.2005-0058

Greenhaus, J.H., Collins, K.M., and Shaw, J.D. 2003. The relation between work-family balance and quality of life. Journal of Vocational Behavior 63 (3): 510-531. http://dx.doi.org/10.1016/S00018791(02)00042-8

Honold, J., Beyer, R., Lakes, T., and Van der Meer, E. 2012. Multiple environmental burdens and neighborhood-related health of city residents. Journal of Environmental Psychology 32 (4): 305-317. http://dx.doi.org/10.1016/j.jenvp.2012.05.002

Heal, L.W., and Chadsey-Rusch, J. 1985. The Lifestyle Satisfaction Scale (LSS): Assessing individuals' satisfaction with residence, community setting, and associated services. Applied Research in Mental Retardation 6 (4): 475-490. http://dx.doi.org/10.1016/0270-3092(85)90022-0

Heckman, J.J. 1981. Statistical models for discrete panel data, In: Manski, C.F., and McFadden, D. (eds.), The Structural Analysis of Discrete Data, Cambridge: MIT Press, 114-178.

Huang, Q., and Sverke, M. 2007. Women's occupational career patterns over 27 years: relations to family of origin, life careers, and wellness. Journal of Vocational Behavior 70 (2): 369-397. http://dx.doi.org/10.1016/j.jvb.2006.12.003

Kaplan, G.A., Shema, S.J., and Leite, C.M.A. 2008. Socioeconomic determinants of psychological wellbeing: the role of income, income change, and income sources during the course of 29 years. Annals of Epidemiology 18 (7): 531-537. http://dx.doi.org/10.1016/j.annepidem.2008.03.006

Khan, U., and Dhar, R. 2007. Where there is a way, is there a will? The effect of future choices on selfcontrol. Journal of Experimental Psychology: General 136(2): 277-88. http://dx.doi.org/10.1037/0096-3445.136.2.277

Kuklinski, J. H., and West, D. M. 1981. Economic expectations and voting behavior in United States House and Senate elections. The American Political Science Review 75(2): 436-447.

Kuwano, M., Zhang, J., and Fujiwara, A. 2011. Dynamic discrete choice model for multiple social interactions. Transportation Research Record 2231: 68-75. http://dx.doi.org/10.3141/2231-09

Lankford, H., and Wyckoff, J. 2006. The effect of school choice and residential location on the racial segregation of students. Advances in Applied Microeconomics 14: 185-239. http://dx.doi.org/10.1016/S0278-0984(06)14008-0 
Lanzendorf, M. 2003. Mobility biographies: A new perspective for understanding travel behavior. Paper presented at the $10^{\text {th }}$ International Conference on Travel Behaviour Research, Lucerne, August 10-15.

Leung, L., and Lee, P.S.N. 2005. Multiple determinants of life quality: the roles of Internet activities, use of new media, social support, and leisure activities. Telematics and Informatics 22 (3): 161-180. http://dx.doi.org/10.1016/j.tele.2004.04.003

Lin, J.H., Wong, J.-Y., and Ho, C.-H. 2013. Promoting frontline employees' quality of life: leisure benefit systems and work-to-leisure conflicts. Tourism Management 36, 178-187. http://dx.doi.org/10.1016/j.tourman.2012.12.009

Litman, T.A. 2005. Land Use Impacts on Transport: How Land Use Factors Affect Travel Behavior. Available at: http://www.vtpi.org/landtravel.pdf (accessed 14 November 2013).

Manski, C. F. 1999. Analysis of choice expectations in incomplete scenarios. Journal of Risk and Uncertainty 19(1-3): 49-65. http://dx.doi.org/10.1023/A:1007806822876

Mokhtarian, P.L., and Salomon, I. 2001. How derived is the demand for travel? Some conceptual and measurement considerations. Transportation Research Part A 35 (8): 695-719.

Mokhtarian, P.L., Salomon, I., and Redmond, L.S. 2001. Understanding the demand for travel: it's not purely "derived." Innovation: The European Journal of Social Science Research 14 (4): 355-380. http://dx.doi.org/10.1080/13511610120106147

Mokhtarian, P.L., and Cao, X. 2008. Examining the impacts of residential self-selection on travel behavior: a focus on methodologies. Transportation Research Part B 42: 204-228. http://dx.doi.org/10.1016/j.trb.2007.07.006

Oakil, A.T.M. 2013. Temporal Dependence in Life Trajectories and Mobility Decisions. Doctoral Dissertation, Utrecht University, The Netherlands (Error! Hyperlink reference not valid.; Accessed November 10, 2013).

Ory, D.T., and Mokhtarian, P.L. 2005. When is getting there half the fun? Modeling the liking for travel. Transportation Research Part A 39 (2/3): 97-124.

Owen, N., Humpel, N., Leslie, E., Bauman, A., and Sallis, J.F. 2004. Understanding environmental influences on walking: Review and research agenda. American Journal of Preventive Medicine 27 (1): 67-76. http://dx.doi.org/10.1016/j.amepre.2004.03.006

Páez, A., and Scott, D.M. 2007. Social influence on travel behavior: a simulation example of the decision to telecommute. Environment and Planning A 39 (3): 647-665. http://dx.doi.org/10.1068/a37424

Pinjari, A.R., Pendyala, R.M., Bhat, C.R., and Waddell, P.A. 2007. Modeling residential sorting effects to understand the impact of the built environment on commute mode choice. Transportation Research Part B 43: 729-748.

Pinjari, A.R., Bhat, C.R., and Hensher, D.A. 2009. Residential self-selection effects in an activity timeuse behavior model. Transportation 34: 557-573.

Salomon, I., and Ben-Akiva, M. 1983. The use of the life-style concept in travel demand models. Environment and Planning A 15(5): 623-638. http://dx.doi.org/10.1068/a150623

Scheiner, J., and Holz-Rau, C. 2013. Changes in travel mode use after residential relocation: a contribution to mobility biographies. Transportation 40 (2): 431-458. http://dx.doi.org/10.1007/s11116012-9417-6

Stead, D. 2008. Institutional aspects of integrating transport, environment and health policies. Transport Policy 15 (3): 139-148. http://dx.doi.org/10.1016/j.tranpol.2007.12.001

Sturm, R., and Cohen, D.A. 2004. Suburban sprawl and physical and mental health. Public Health 118 (7): 488-496. http://dx.doi.org/10.1016/j.puhe.2004.02.007

Swait, J., Adamowicz, W., and van Bueren, M. (2004) Choice and temporal welfare impacts: incorporating history into discrete choice models. Journal of Environmental Economics and Management 47 (1): 94-116. http://dx.doi.org/10.1016/S0095-0696(03)00077-9

Tefft, N. 2012. Mental health and employment: the SAD story. Economics \& Human Biology 10 (3): 242-255. http://dx.doi.org/10.1016/j.ehb.2011.08.006 
Van der Klaauw, W. 2012. On the use of expectations data in estimating structural dynamic choice models. Journal of Labor Economics 30(3): 521-554. http://dx.doi.org/10.1086/664929

Van der Klaauw, W., and Wolpin, K. I. 2008. Social security and the retirement and savings behavior of low income households. Journal of Econometrics 145(1-2): 21-42. http://dx.doi.org/10.1016/j.jeconom.2008.05.004

Van der Waerden, P.J.H.J., Borgers, A.W.J., and Timmermans, H.J.P. 2003. Key events and critical incidents influencing transport mode choice switching behavior: an exploratory study. Compendium of Papers CD-ROM, The 82nd Annual Meeting of Transportation Research Board. Washington, D.C., January 12-16.

Van Wee, B. 2009. Self-selection: A key to a better understanding of location choices, travel behavior and transport externalities?. Transport Review 29 (3): 279-292. http://dx.doi.org/10.1080/01441640902752961

Verhoeven, M. 2010. Modelling Life Trajectories and Mode Choice Using Bayesian Belief Networks. Doctoral Disseration, Eindhoven University of Technology.

Vij, A., Carrel, A., and Walker, J.L. 2013. Incorporating the influence of latent modal preferences on travel mode choice behavior. Transportation Research Part A 54: 164-178.

Walker, J.L., Ehlers, E., Banerjee, I., and Dugundji, E.R. 2011. Correcting for endogeneity in behavioral choice models with social influence variables. Transportation Research Part A 45: 362-374.

Walker, J.L., and Li, J. 2007. Latent lifestyle preferences and household location decisions. Journal of Geographical Systems 9(1): 77-101. http://dx.doi.org/10.1007/s10109-006-0030-0

Wang, Z., Zhang, J., and Fujiwara, A. 2010. Representing the dynamics in stated travel choice behavior based on a DGEV model with heterogeneity. Journal of the Eastern Asia Society for Transportation Studies 8: 564-578.

Werner, L.R.C. 2011. Residential satisfaction among aging people living in place. Journal of Environmental Psychology 31 (2): 158-169. http://dx.doi.org/10.1016/j.jenvp.2010.12.001

Winters, J.V., 2011. Human capital, higher education institutions, and quality of life. Regional Science and Urban Economics 41 (5): 446-454. http://dx.doi.org/10.1016/j.regsciurbeco.2011.03.001

World Health Organization (WHO). 2004. Global Strategy on Diet, Physical Activity and Health: Report by the Secretariat. Geneva.

Xiong, Y., and Zhang, J. 2014. How do residential environment and travel behavior influence people's life satisfaction? Bayesian network analysis. Compendium of Papers CD-ROM, the 93rd Annual Meeting of the Transportation Research Board, Washington D.C., January 12-16.

Yu, B., Zhang, J., and Fujiwara, A. 2012. Analysis of the residential location choice and household energy consumption behavior by incorporating multiple self-selection effects. Energy Policy 46: 319-334. http://dx.doi.org/10.1016/j.enpol.2012.03.067

Zhang, H., Zhang, J., and Kuwano, M. 2012(a). An integrated model of tourists' time use and expenditure behavior with self-selection based on a fully-nested Archimedean copula function. Tourism Management 33(6): 1562-1573. http://dx.doi.org/10.1016/j.tourman.2012.03.004

Zhang, J., and Fujiwara, A. 2006. Representing household time allocation behavior by endogenously incorporating diverse intra-household interactions: A case study in the context of elderly couples. Transportation Research Part B 40 (1): 54-74. http://dx.doi.org/10.1016/j.trb.2005.01.004

Zhang, J., Sugie, Y., and Fujiwara, A. 2004. Representing travel choice behavior dynamics based on cross-sectional and longitudinal heterogeneity. Journal of Infrastructure Planning and Management 765/IV-64: 3-15.

Zhang, J., Timmermans, H.J.P., and Borgers, A. 2002. A utility-maximizing model of household time use for independent, shared and allocated activities incorporating group decision mechanisms. Transportation Research Record 1807: 1-8. http://dx.doi.org/10.3141/1807-01 
Zhang, J., Tsuchiya, Y., Fujiwara, A., and Chikaraishi, M. 2011. Citizens' life decisions and behavior survey: proposal and application to the evaluation of quality of life. Proceedings of Infrastructure Planning 43 (CD-ROM) (in Japanese).

Zhang, J., Tsuchiya, Y., Hinohara, H., and Chikaraishi, M. 2012b. Citizens' life behavior and quality of life: Survey and modeling. Paper presented at the IATUR (International Association for Time Use Research) 34th Annual Conference, Matsue City, Japan, August 22-24.

Zhang, J., Yu, B., and Chikaraishi, M. 2013. Interdependences between household residential and car ownership behavior: a life history analysis. Journal of Transport Geography (forthcoming)

Zhang, J. 2010. Modeling inter-personal interactions in activity-travel behavior. Keynote Speech at the 7th International Conference on Traffic and Transportation Studies, Kunming, China, August 3-5.

Zhang, J. 2012. From activity-based to life-oriented approach: Interdisciplinary challenges. Invited Speech at the International Seminar on Applications of Activity-based Transportation Modeling in Simulation and ICT Impacts, Korea Research Institute for Human Settlements (KRIHS) and TODbased Engineering Research Center (TOD ERC), Seoul, South Korea, October 19.

Zhang, J., and Xiong, Y. 2013. Effects of life choices on the quality of life: A case study in Japan based on a combined Exhaustive CHAID and Bayesian Belief Network Approach. Invited Speech at the Seminar 'Advances in Happiness Economics', Erasmus University Rotterdam, The Netherlands, October 28-29.

Zimmerman, C.A. 1982. The life cycle concept as a tool for travel research. Transportation 11 (1): 5169. http://dx.doi.org/10.1007/BF00165594 